\title{
Mayer-Rokitansky-Küster-Hauser syndrome type 2
}

INSERM

\section{Source}

INSERM. (1999). Orphanet: an online rare disease and orphan drug data base. MayerRokitansky-Küster-Hauser syndrome type 2. ORPHA:2578

Mayer-Rokitansky-Küster-Hauser (MRKH) syndrome type 2, a form of MRKH syndrome (see this term), is characterized by congenital aplasia of the uterus and upper $2 / 3$ of the vagina that is associated with at least one other malformation such as renal, vertebral, or, less commonly, auditory and cardiac defects. The acronym MURCS (MÜllerian duct aplasia, Renal dysplasia, Cervical Somite anomalies) is also used. 